\title{
Calcium influx in mammalian eggs
}

\author{
Chunmin Wang and Zoltan Machaty \\ Department of Animal Sciences, Purdue University, 915 West State Street, West Lafayette, Indiana 47907, USA
}

Correspondence should be addressed to Z Machaty; Email: zmachaty@purdue.edu

\begin{abstract}
Calcium $\left(\mathrm{Ca}^{2+}\right)$ signals are involved in the regulation of oocyte maturation and play a critical role during fertilization. In the egg, $\mathrm{Ca}^{2+}$ is stored in the lumen of the endoplasmic reticulum and a signal is generated when the stored $\mathrm{Ca}^{2+}$ is released through specialized channels in the membrane of the endoplasmic reticulum to elevate the free $\mathrm{Ca}^{2+}$ concentration in the cytoplasm. Extracellular $\mathrm{Ca}^{2+}$ is also important, indicated by the fact that the mobilization of luminal $\mathrm{Ca}^{2+}$ is typically followed by $\mathrm{Ca}^{2+}$ entry across the plasma membrane. The transmembrane $\mathrm{Ca}^{2+}$ flux replenishes the endoplasmic reticulum, and thus, it is essential to sustain prolonged $\mathrm{Ca}^{2+}$ signals. It also seems to be responsible for the stimulation of important signaling cascades required for complete egg activation. Characterization of the pathway that mediates $\mathrm{Ca}^{2+}$ entry implies that its major components include STIM1, a protein that senses the filling status of the stores,

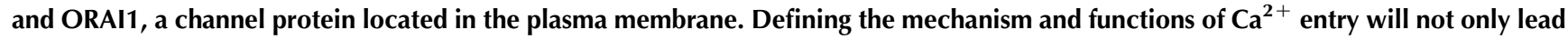
to a better understanding of egg physiology but may also help improving the efficiency of a number of assisted reproductive technologies. Reproduction (2013) 145 R97-R105
\end{abstract}

\section{Introduction}

The calcium ion $\left(\mathrm{Ca}^{2+}\right)$ is the most universal signaling messenger that regulates a wide array of cellular processes (Berridge et al. 1998). It carries messages by reversibly attaching to $\mathrm{Ca}^{2+}$-binding sites of proteins; $\mathrm{Ca}^{2+}$ binding changes the shape and charge of proteins and confers new functions to them. A series of proteins and signaling molecules then make up a signaling cascade that transduces signals between or within cells. Because prolonged exposure to high $\mathrm{Ca}^{2+}$ concentration is detrimental, cells maintain cytosolic $\mathrm{Ca}^{2+}$ levels low, 20000 -fold lower than that in the extracellular space. For this purpose, $\mathrm{Ca}^{2+}$ can be chelated by specialized proteins, stored in intracellular compartments or pumped out the cell. For signaling, the $\mathrm{Ca}^{2+}$ concentration in the cytosol is elevated briefly and this can be achieved by releasing $\mathrm{Ca}^{2+}$ from the intracellular stores or letting external $\mathrm{Ca}^{2+}$ in through ion channels located in the plasma membrane. Cells employ a set of signaling, homeostatic, and sensory mechanisms to shape $\mathrm{Ca}^{2+}$ signals in space and time (Bootman et al. 2001). In the female gamete, $\mathrm{Ca}^{2+}$ signals drive important biological processes and $\mathrm{Ca}^{2+}$ released from the endoplasmic reticulum contribute primarily to the generation of the signals. Although extracellular $\mathrm{Ca}^{2+}$ is also essential for proper signaling, relatively little is known about the mechanism that mediates the entry of $\mathrm{Ca}^{2+}$ across the plasma membrane. The aim of this review is to summarize the information that is available about $\mathrm{Ca}^{2+}$ entry in mammalian eggs with special emphasis on the most recent findings.

\section{The source of $\mathrm{Ca}^{2+}$ during signaling}

In some cell types, $\mathrm{Ca}^{2+}$ signaling depends primarily on the entry of extracellular $\mathrm{Ca}^{2+}$ (Clapham 2007). In excitable cells, certain external stimuli are able to depolarize the plasma membrane. Membrane depolarization then activates voltage-gated $\mathrm{Ca}^{2+}$ channels, thus creating an influx of $\mathrm{Ca}^{2+}$ across the plasma membrane. The $\mathrm{Ca}^{2+}$ that enters the cell will initiate various cellular events either directly by increasing intracellular $\mathrm{Ca}^{2+}$ levels or indirectly by inducing $\mathrm{Ca}^{2+}$ release from the sarcoplasmic reticulum.

Cells that cannot use membrane depolarization to trigger a $\mathrm{Ca}^{2+}$ influx rely on the release of $\mathrm{Ca}^{2+}$ from intracellular stores to elevate their intracellular free $\mathrm{Ca}^{2+}$ concentrations (Van Den Brink et al. 1999). Stimulation of cell surface receptors in such cells activates the phosphoinositide signaling system leading to $\mathrm{Ca}^{2+}$ release from the endoplasmic reticulum and the generation of $\mathrm{a} \mathrm{Ca}^{2+}$ signal. These cells, however, can also use the external source of $\mathrm{Ca}^{2+}$ during signaling. The release of $\mathrm{Ca}^{2+}$ from the internal store is generally followed by a $\mathrm{Ca}^{2+}$ influx across the plasma membrane. The $\mathrm{Ca}^{2+}$ that enters the cells is believed to be necessary to replace $\mathrm{Ca}^{2+}$ pumped out of the cell during the period 
of high $\mathrm{Ca}^{2+}$ levels (Rink \& Hallam 1989); it refills the intracellular stores, provides $\mathrm{Ca}^{2+}$ for long-lasting plateau signals, and also sustains repetitive $\mathrm{Ca}^{2+}$ oscillations (reviewed by Prakriya (2009)).

The origin of $\mathrm{Ca}^{2+}$ during signaling may vary depending on a number of factors. During fertilization for example, eggs of many species including most marine invertebrates, fish, and frogs show an action potential and $\mathrm{Ca}^{2+}$ influx as a result of this depolarization is part of the signaling mechanism responsible for their activation. Some of these (e.g. the echiuran worm Urechis) rely almost entirely on the $\mathrm{Ca}^{2+}$ entry for successful fertilization; in others such as sea urchins, the initial influx is followed by a release of $\mathrm{Ca}^{2+}$ from internal stores and the mobilized intraluminal $\mathrm{Ca}^{2+}$ provides the primary trigger for activation (Stricker 1999). The situation in mammalian eggs is slightly different. Hamster and mouse eggs do not show depolarization at fertilization; also, their resting membrane potential of -30 to $-40 \mathrm{mV}$ inactivates voltagegated $\mathrm{Ca}^{2+}$ channels (Miyazaki \& Igusa 1981a, Igusa et al. 1983). Due to these reasons, in such eggs, the fertilization $\mathrm{Ca}^{2+}$ signal is primarily provided by $\mathrm{Ca}^{2+}$ release from the intracellular stores and not by $\mathrm{Ca}^{2+}$ entry across the plasma membrane. Nevertheless, an increasing line of evidences now indicates that $\mathrm{Ca}^{2+}$ influx in mammalian eggs does have an important role to play.

\section{$\mathrm{Ca}^{2+}$ influx during oocyte maturation}

Before ovulation, mammalian oocytes are arrested at the first meiotic prophase in the ovarian follicles (Edwards 1965). During the control of meiosis, a high level of cAMP in the oocyte cytoplasm that originates from the surrounding granulosa cells is probably critical for maintaining the first meiotic arrest (Dekel \& Beers 1978). Under physiological conditions, oocyte maturation is triggered by an $\mathrm{LH}$ surge (or it can occur spontaneously, after the removal from the follicle environment) that leads to the disruption of gap junctions between the oocyte and the granulosa cells (Gilula et al. 1978) and a drop in cAMP levels (Eppig \& Downs 1988). cAMP in known to suppress the activity of the M-phase promoting factor (MPF) through cAMP-dependent protein kinase $\mathrm{A}(\mathrm{PKA})$; thus, a decrease in cAMP concentrations leads to the activation of MPF. Active MPF then stimulates the progression of the cell cycle from the G2 to the M-phase and germinal vesicle breakdown (GVBD) occurs (reviewed by Downs (2010)). Additional factors such as downregulation of cGMP levels (Norris et al. 2009, Vaccari et al. 2009) and activation of the MAP kinase cascade (Fan et al. 2009) are also believed to be crucial in the induction and progression of meiosis. A great deal of experimental data suggests, however, that $\mathrm{Ca}^{2+}$ signals also play a regulatory role in meiotic maturation. Early observations in the mouse indicated that extracellular $\mathrm{Ca}^{2+}$ was essential for meiotic resumption (De Felici \& Siracusa 1982, Racowsky 1986). It was then reported that immature mouse and hamster oocytes showed a series of spontaneous $\mathrm{Ca}^{2+}$ oscillations after being released from antral follicles and the oscillations lasted until GVBD (Carroll \& Swann 1992, Fujiwara et al. 1993). Although the $\mathrm{Ca}^{2+}$ oscillations in mouse oocytes were caused by an increase in inositol 1,4,5-trisphosphate $\left(\right.$ Ins $\left.P_{3}\right), \mathrm{Ca}^{2+}$ influx inhibitors rapidly blocked the repetitive $\mathrm{Ca}^{2+}$ transients indicating the involvement of $\mathrm{Ca}^{2+}$ entry in the signaling process. Interestingly, the spontaneous oscillations did not serve as a trigger for meiotic resumption as inhibition of the signals with a $\mathrm{Ca}^{2+}$ chelator had no effect on the onset of GVBD (Carroll \& Swann 1992). Other studies led to similar conclusions: GVBD was $\mathrm{Ca}^{2+}$ independent and proceeded without interruption in the absence of extracellular $\mathrm{Ca}^{2+}$ but completion of the first meiotic division did not occur without $\mathrm{Ca}^{2+}$ in the holding medium (Paleos \& Powers 1981, Tombes et al. 1992). This again indicated the importance of $\mathrm{Ca}^{2+}$ entry across the plasma membrane in meiotic maturation. Speciesspecific differences clearly exist, as in bovine (Homa 1991) and pig oocytes (Kaufman \& Homa 1993), chelating $\mathrm{Ca}^{2+}$ inhibited GVBD; in the pig, an influx of $\mathrm{Ca}^{2+}$ was also a prerequisite for development beyond the metaphase I stage (Kaufman \& Homa 1993).

The mechanism that mediates $\mathrm{Ca}^{2+}$ entry during maturation is not known in detail. The result of early studies indicated the involvement of unspecific voltagegated calcium channels, and an increase in the number of such channels together with a gradual depolarization of the plasma membrane was also shown to occur during oocyte growth when the female gamete gains meiotic competence (Murnane \& De Felice 1993). This implies that such channels may carry a $\mathrm{Ca}^{2+}$ current to control the onset of maturation. Another study described the presence of functional L-type voltage-gated $\mathrm{Ca}^{2+}$ channels in mouse oocytes that were missing from GVBD-arrested oocytes, suggesting that such channels were necessary for maturation (Lee et al. 2004). In addition, inward currents through L-type voltage-gated channels were detected in immature bovine (Tosti et al. 2000) and sheep (Boni et al. 2005) oocytes, although in cattle their activity decreased by the end of maturation. Finally, in pig oocytes, P-type voltage-gated $\mathrm{Ca}^{2+}$ channels were identified and their activation by membrane depolarization led to a prolonged increase in cytoplasmic $\mathrm{Ca}^{2+}$ levels and eventually maturation of the oocyte (Gioia et al. 2005). These findings may indicate the involvement of $\mathrm{Ca}^{2+}$ influx via voltagegated channels in the G2/M transition.

Similarly, there is no complete agreement on the exact function of $\mathrm{Ca}^{2+}$ as a transducer of the maturation signal. As mentioned earlier, cAMP is a crucial molecule in the cascade that controls the maintenance of the arrest 
at prophase of the first meiotic cell division. It activates PKA that in turn inhibits MPF through the phosphorylation of mediating proteins (Downs 2010, Luciano et al. 2011). The question is whether $\mathrm{Ca}^{2+}$ signals exert any control over the downregulation of cAMP levels at the beginning of maturation. In spontaneously maturing mouse oocytes, the phosphoinositide signaling pathway may play a regulatory role (Lefevre et al. 2007), whereas gonadotropin-induced oocyte maturation was suggested to be $\mathrm{Ca}^{2+}$ independent (Mehlmann et al. 2006). What seems to support the regulatory function of $\mathrm{Ca}^{2+}$ is the observation that the preovulatory $\mathrm{LH}$ surge generates a $\mathrm{Ca}^{2+}$ signal in the cumulus cells that is transmitted to the oocyte (Mattioli et al. 1998, Webb et al. 2002). This $\mathrm{Ca}^{2+}$ signal may be involved in controlling intracytoplasmic CAMP levels by modulating the activity of $\mathrm{Ca}^{2+}$ sensitive adenylate cyclases during both spontaneous and gonadotropin-induced oocyte maturation (Silvestre et al. 2011).

\section{$\mathrm{Ca}^{2+}$ influx during fertilization}

At the time of ovulation, mammalian eggs are arrested at the metaphase stage of their second meiotic cell division. They are released from this second meiotic arrest and embryo development is stimulated during fertilization, when the sperm triggers a prolonged series of $\mathrm{Ca}^{2+}$ oscillations in the egg cytoplasm. Research has shown that the oscillations are the result of the release of $\mathrm{Ca}^{2+}$ from the egg's intracellular stores; the release is induced by the protein phospholipase Czeta (PLC $\zeta$ ) that diffuses from the sperm into the ooplasm after gamete fusion (Saunders et al. 2002). The released $\mathrm{Ca}^{2+}$ binds calmodulin and $\mathrm{Ca}^{2+}$-bound calmodulin activates $\mathrm{Ca}^{2+}$ /calmodulin-dependent protein kinase II (CaMKII) that stimulates a signaling cascade leading to the downregulation of the MPF and eventually exit from meiosis (Whitaker 2006).

The series of sperm-induced $\mathrm{Ca}^{2+}$ transients were first demonstrated indirectly, in hamster eggs, as periodic hyperpolarizations of the egg's plasma membrane (Miyazaki \& Igusa 1981a). The hyperpolarizations were caused by a potassium conductance, which in turn was stimulated by the transient elevations in the intracellular free $\mathrm{Ca}^{2+}$ levels. The transients were then observed directly in mouse eggs using the $\mathrm{Ca}^{2+}$-sensitive photoprotein aequorin (Cuthbertson et al. 1981, Cuthbertson \& Cobbold 1985). The series of $\mathrm{Ca}^{2+}$ transients stopped upon the removal of extracellular $\mathrm{Ca}^{2+}$ and its frequency also depended on the $\mathrm{Ca}^{2+}$ concentration outside of the cell (Igusa \& Miyazaki 1983). Based on these observations, it was hypothesized that $\mathrm{Ca}^{2+}$ entry was a key element of the spiking mechanism in mammalian eggs. Subsequent findings that identified $\operatorname{Ins}_{3}$ as a $\mathrm{Ca}^{2+}$-mobilizing second messenger (Streb et al. 1983), the demonstration that its level increased during fertilization (Turner et al.
1984), and the discovery that its injection into the egg stimulated parthenogenetic activation (Whitaker \& Irvine 1984) established that $\operatorname{InsP}_{3}$ was the molecule that had a key role in generating the fertilization $\mathrm{Ca}^{2+}$ signal by triggering the release of $\mathrm{Ca}^{2+}$ from intracellular stores. The sperm-induced $\mathrm{Ca}^{2+}$ transients seemed to be associated with a continuous $\mathrm{Ca}^{2+}$ influx, and a linkage between the $\mathrm{Ca}^{2+}$ influx and $\mathrm{Ca}^{2+}$ release from the intracellular stores was also suggested. However, the identity of the transport system through which $\mathrm{Ca}^{2+}$ passed through the plasma membrane was not known. Voltage-gated $\mathrm{Ca}^{2+}$ channels present in the plasma membrane of hamster eggs (Miyazaki \& Igusa 1981b) were ruled out mostly because the frequency of the hyperpolarization responses increased on hyperpolarization. A model of $\mathrm{Ca}^{2+}$ oscillations was later proposed where the fertilizing sperm increased the permeability of the plasma membrane and the $\mathrm{Ca}^{2+}$ influx was essential not only for providing favorable conditions for the discharge of $\mathrm{Ca}^{2+}$ but also for the refilling of the $\mathrm{Ca}^{2+}$ pools to release $\mathrm{Ca}^{2+}$ again (Miyazaki 1991).

The dependence of the oscillations on extracellular $\mathrm{Ca}^{2+}$ was also demonstrated in mouse eggs. By using fluorescent $\mathrm{Ca}^{2+}$ indicators to monitor intracellular free $\mathrm{Ca}^{2+}$ levels, these experiments revealed that the sperminduced $\mathrm{Ca}^{2+}$ oscillations rapidly stopped or their frequency significantly decreased upon chelation of external $\mathrm{Ca}^{2}+$ (Kline \& Kline 1992, Shiina et al. 1993). In addition, depleting the intracellular stores with thapsigargin, a plant-derived inhibitor of the sarcoplasmic/endoplasmic reticulum $\mathrm{Ca}^{2+}$ ATPase, activated a $\mathrm{Ca}^{2+}$ influx across the plasma membrane in unfertilized eggs and suppressed the train of $\mathrm{Ca}^{2+}$ spikes in fertilized ones (Kline \& Kline 1992). This indicated that a mechanism known in somatic cells as store-operated $\mathrm{Ca}^{2+}$ entry was functional in mouse eggs as well and implied that it was essential to refill the stores and maintain the $\mathrm{Ca}^{2+}$ oscillations. Further evidence regarding the existence of $\mathrm{Ca}^{2+}$ influx during fertilization came from experiments using the sulfhydryl reducing agent dithiothreitol (DTT). In unfertilized mouse eggs, DTT increased the rate of divalent cation influx while in fertilized eggs it was able to accelerate the frequency of the sperm-induced $\mathrm{Ca}^{2+}$ transients (Cheek et al. 1993). This again implied that the influx of external $\mathrm{Ca}^{2+}$ played an important part in signaling during fertilization.

The precise linkage between the $\mathrm{Ca}^{2+}$ influx and the train of $\mathrm{Ca}^{2+}$ spikes was determined using the manganese $\left(\mathrm{Mn}^{2+}\right)$-quench technique (McGuinness et al. 1996). When added to the extracellular medium, $\mathrm{Mn}^{2+}$ acts as a $\mathrm{Ca}^{2+}$ surrogate: it can cross the plasma membrane and bind the $\mathrm{Ca}^{2+}$ indicator dye fura- 2 . Binding quenches the fluorescence of fura-2 and this enables the measurement of divalent cation influx. This study revealed that in fertilized mouse eggs, the rising phase of each $\mathrm{Ca}^{2+}$ transient was followed by the 
stimulation of a $\mathrm{Ca}^{2+}$ influx across the plasma membrane. In addition, a smaller yet notable increase in $\mathrm{Ca}^{2+}$ influx persisted during the periods between the spikes. Again, although the presence of voltage-gated $\mathrm{Ca}^{2+}$ channels had previously been reported in mouse eggs (Murnane \& De Felice 1993, Day et al. 1995), these cells show only negligible hyperpolarizations during $\mathrm{Ca}^{2+}$ transients (Igusa et al. 1983). Thus, the authors hypothesized that the spike-associated $\mathrm{Ca}^{2+}$ influx was probably controlled by the filling status of the internal stores. A similar conclusion was reached by Mohri et al. (2001) after injecting a sperm extract into mouse eggs to stimulate repetitive $\mathrm{Ca}^{2+}$ oscillations. The injections were followed by a persistent $\mathrm{Ca}^{2+}$ influx that was activated during the initial $\mathrm{Ca}^{2+}$ release from the intracellular stores, possibly by a store-operated mechanism. The continuous $\mathrm{Ca}^{2+}$ influx was apparently responsible for refilling the stores and sustaining the $\mathrm{Ca}^{2+}$ oscillations.

The $\mathrm{Ca}^{2+}$ entry that is stimulated by the filling status of the $\mathrm{Ca}^{2+}$ store seems to be under the control of protein kinase $\mathrm{C}$ (PKC). It was known for quite some time that phorbol esters such as 12-O-tetradecanoylphorbol acetate (TPA) or phorbol-12-myristate-13-acetate (PMA), potent stimulators of PKC, caused low-amplitude $\mathrm{Ca}^{2+}$ oscillations, ZP2 modification, zona hardening, and cortical granule exocytosis in mouse eggs (Cuthbertson \& Cobbold 1985, Endo et al. 1986, Colonna et al. 1989, Ducibella et al. 1991). Similarly, 1-oleyl-2-acetylsn-glycerol (OAG), a synthetic analog of endogenous diacylglycerol (DAG, the physiological activator of PKC) promoted mouse egg activation (Colonna et al. 1989). Further evidence came from the observation that during $\mathrm{Ca}^{2+}$ oscillations in fertilized mouse eggs, fluorescently labeled PKCs translocated to the egg plasma membrane repeatedly and the pattern of translocation followed that of the $\mathrm{Ca}^{2+}$ transients and also the periodic increases in the rate of $\mathrm{Ca}^{2+}$ influx (Halet et al. 2004). In addition, inhibition of PKCs with bisindolylmaleimide I (BIM) not only blocked $\mathrm{Ca}^{2+}$ influx after store depletion induced by thapsigargin but also terminated the sperm-induced $\mathrm{Ca}^{2+}$ oscillations. On the other hand, the PKC agonist PMA stimulated store-operated $\mathrm{Ca}^{2+}$ entry and promoted the long-lasting $\mathrm{Ca}^{2+}$ signal at fertilization. In similar studies, PKC activation promoted $\mathrm{Ca}^{2+}$ influx and repetitive $\mathrm{Ca}^{2+}$ oscillations (Yu et al. 2008) and constitutively active PKC constructs triggered a persistent elevation in cytosolic $\mathrm{Ca}^{2+}$ levels after the mobilization of luminal $\mathrm{Ca}^{2+}$ (Madgwick et al. 2005). It was hypothesized that the $\mathrm{Ca}^{2+}$ entry channel or some accessory proteins at the plasma membrane became phosphorylated by PKC that in turn caused an increase in $\mathrm{Ca}^{2+}$ entry. Interestingly, the store depletion-activated $\mathrm{Ca}^{2+}$ influx in somatic cells was inhibited, rather than stimulated, by PKC activation (Parekh \& Penner 1995, Haverstick et al. 1997), and later it was demonstrated that PKC suppressed $\mathrm{Ca}^{2+}$ entry by phosphorylating
ORAI1, the protein that forms the store-operated $\mathrm{Ca}^{2+}$ entry channel (Kawasaki et al. 2010). The reason for this difference is not clear. It is possible that proteins of the store-operated $\mathrm{Ca}^{2+}$ entry cascade are not substrates for PKC in eggs (other isoforms of the ORAI protein such as ORAI2 and ORAI3 are not targeted by PKC inhibitory phosphorylation and mouse eggs may use such proteins as the pore-forming subunit as their store-operated $\mathrm{Ca}^{2+}$ channel) and PKC stimulates $\mathrm{Ca}^{2+}$ influx through a completely different mechanism. Alternatively, differences in the various PKC subtypes or variations in the molecular composition of store-operated $\mathrm{Ca}^{2+}$ entry channels in different cell types may explain the diverse effects of PKC on $\mathrm{Ca}^{2+}$ entry. In addition, the level of PKC activation may also be important: in Xenopus oocytes, low level of PKC activation promoted storeoperated $\mathrm{Ca}^{2+}$ entry while high degree of PKC activity had an inhibitory effect (Petersen \& Berridge 1994). Overall, these findings suggested that PKC controlled cytoplasmic $\mathrm{Ca}^{2+}$ levels in eggs, and it may do so through a store-operated entry mechanism.

The onset of a $\mathrm{Ca}^{2+}$ influx triggered by the depletion of the intracellular stores was later demonstrated in pig (Machaty et al. 2002) and human (Martín-Romero et al. 2008) eggs as well. This further extended the list of mammalian eggs in which the mechanism of storeoperated $\mathrm{Ca}^{2+}$ entry was shown to be functional. The molecular components of the pathway were clarified soon after the identity of these proteins became known in somatic cell types. Limited RNAi screens in human HeLa (Liou et al. 2005) and Drosophila S2 (Roos et al. 2005) cells identified stromal interacting molecules (STIM) in the endoplasmic reticulum. STIM proteins (STIM1 and STIM2) are single transmembrane proteins that sense $\mathrm{Ca}^{2+}$ content with a canonical EF hand directed toward the lumen of the $\mathrm{Ca}^{2+}$ store. Upon store depletion, STIM1 translocates to the plasma membrane and activates $\mathrm{Ca}^{2+}$ influx; STIM2 is activated by smaller decreases in luminal $\mathrm{Ca}^{2+}$ and therefore functions to stabilize basal $\mathrm{Ca}^{2+}$ levels in the cytoplasm and the endoplasmic reticulum (Brandman et al. 2007). The proteins that form the channel pore were discovered through whole genome RNAi screens in Drosophila S2 cells (Feske et al. 2006, Vig et al. 2006, Zhang et al. 2006) and named ORAI after the gatekeepers of heaven in Greek mythology. Of the three ORAI proteins (ORAI1-3) identified, ORAI1 is the most potent; it is located in the plasma membrane and when stimulated by STIM1, it lets $\mathrm{Ca}^{2+}$ flow into the cytoplasm from the extracellular space.

The presence of STIM1 has been demonstrated in pig (Koh et al. 2007) and mouse (Gómez-Fernández et al. 2009) eggs. In the pig, STIM1 expression was shown by PCR amplification using oligonucleotide primers based on a porcine EST sequence that showed high similarity to human and mouse STIM1. In resting cells, STIM1 co-localized with the endoplasmic reticulum and 
pharmacological store depletion triggered its redistribution in regions close to the plasma membrane. STIM1 overexpresssion led to an increase in $\mathrm{Ca}^{2+}$ influx after depletion of luminal $\mathrm{Ca}^{2+}$ whereas the influx was inhibited in the presence of store-operated $\mathrm{Ca}^{2+}$ channel blockers or after suppression of STIM1 expression with siRNAs (Koh et al. 2009). Additional experiments implicated the involvement of STIM1 in the signaling process during fertilization. The protein rapidly re-distributed at the plasma membrane following fertilization (Gómez-Fernández et al. 2009). In addition, downregulation of STIM1 expression using siRNAs in pig eggs completely abolished the repetitive $\mathrm{Ca}^{2+}$ oscillations at fertilization and had a negative effect on subsequent embryo development. Ionomycin added to fertilized eggs that stopped oscillating due to downregulated STIM1 levels was able to mobilize only a small amount of $\mathrm{Ca}^{2+}$ compared with that in control eggs, indicating that the stores were not properly refilled in the absence of STIM1. Restoring STIM1 levels in these eggs following fertilization did not rescue embryo development, suggesting that it was at earlier stages when the function of STIM1 was necessary. Finally, as expected, STIM1 downregulation was without effect on egg activation when development was stimulated parthenogenetically, by triggering a single rise in the egg's cytosolic free $\mathrm{Ca}^{2+}$ levels (Lee et al. 2012). These results seem to suggest that STIM1 is essential to maintain the repetitive $\mathrm{Ca}^{2+}$ signal by mediating store-operated $\mathrm{Ca}^{2+}$ entry during fertilization.

The channel component of the store-operated $\mathrm{Ca}^{2+}$ entry cascade, ORAI1, is also present and functional in pig and mouse eggs. Both indirect immunocytochemistry and overexpression of fluorescently tagged ORAI1 revealed that ORAI1 was present mostly in the cell cortex consistent with plasma membrane localization. Expression of ORAI1 decreased in pig eggs during maturation with STIM1 levels remaining fairly constant (Wang et al. 2012); this was different in mouse eggs where ORAI1 expression levels were unaltered during maturation while STIM1 was expressed only at very low levels in the GV-stage oocyte (Gómez-Fernández et al. 2012). Despite these species-specific differences in the expression levels of these signaling proteins, the effect of the changes seems to be the same in both species: to enhance the small store-operated $\mathrm{Ca}^{2+}$ influx measured in GV-stage oocytes to a much higher level by the time the oocytes complete maturation and are ready for fertilization. Downregulation of ORAI1 expression with siRNAs blocked $\mathrm{Ca}^{2+}$ entry induced by pharmacological depletion of the intracellular stores and also abolished the repetitive $\mathrm{Ca}^{2+}$ oscillations in fertilized eggs. Furthermore, embryo development stimulated by the abnormal fertilization $\mathrm{Ca}^{2+}$ signals in eggs with

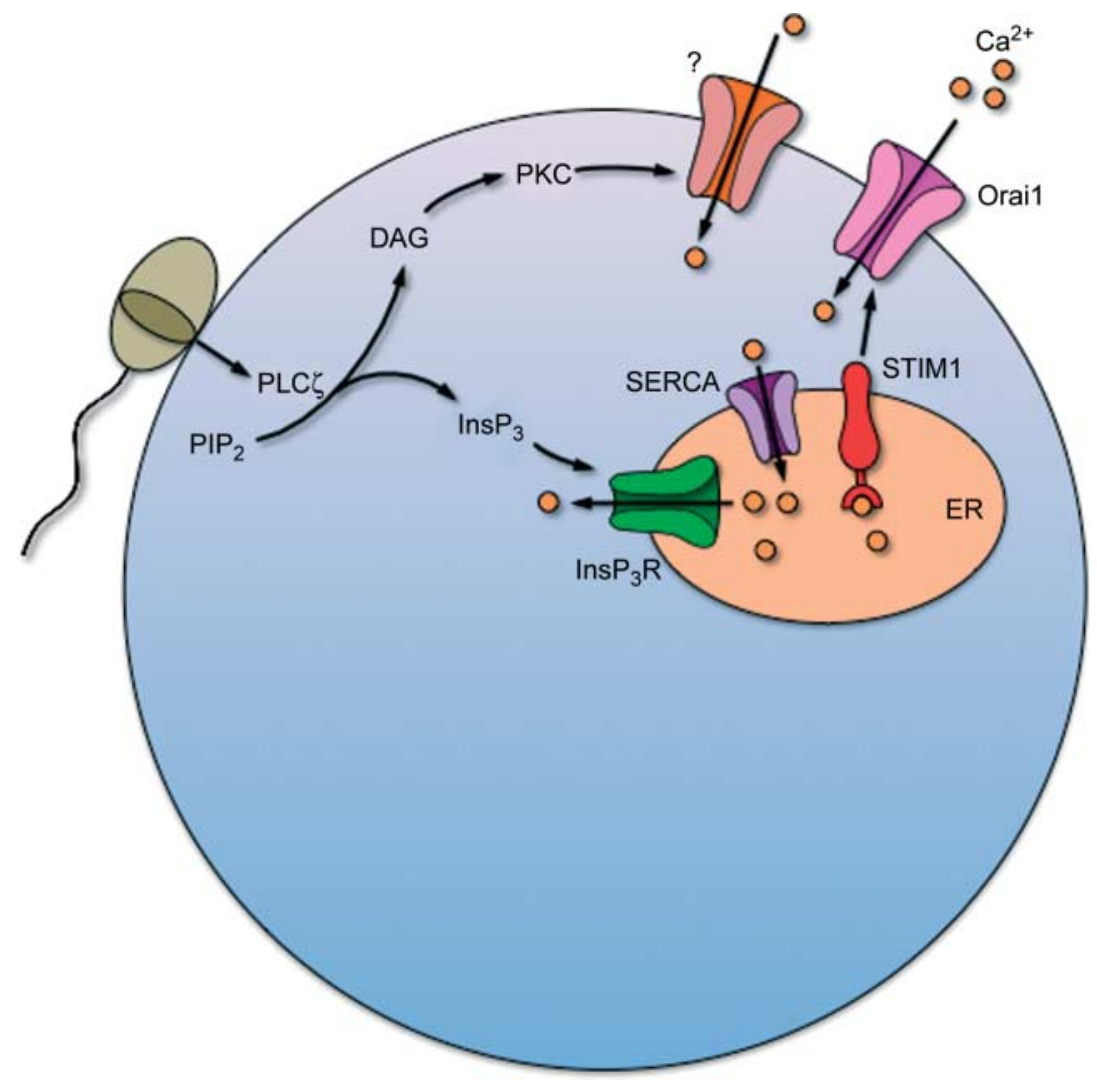

Figure 1 Schematic of $\mathrm{Ca}^{2+}$ entry during fertilization. Sperm-derived PLC $\zeta$ cleaves $\mathrm{PIP}_{2}$ and generates $\operatorname{Ins}_{3}$ that triggers $\mathrm{Ca}^{2+}$ release from the endoplasmic reticulum. Results in pig oocytes seem to indicate that STIM1 senses store depletion and transmits the empty signal to the plasma membrane where it opens ORAI1 channels and induces storeoperated $\mathrm{Ca}^{2+}$ entry (Lee et al. 2012, Wang et al. 2012). Recent data from mouse oocytes did not support the involvement of a store-operated entry mechanism (Miao et al. 2012, Takahashi et al. 2013). Nevertheless, $\mathrm{Ca}^{2+}$ entering the cell is pumped back into the store and another $\mathrm{Ca}^{2+}$ transient will be generated. The other product of $\mathrm{PIP}_{2}$ hydrolysis, DAG, may activate PKC that promotes $\mathrm{Ca}^{2+}$ influx through a yet-to-be identified $\mathrm{Ca}^{2+}$ entry channel. 
downregulated ORAI1 was severely impaired. On the other hand, overexpression of ORAI1 together with STIM1 resulted in a huge increase in $\mathrm{Ca}^{2+}$ influx induced by artificial depletion of the intracellular stores. These data suggest that the cascade that mediates storeoperated $\mathrm{Ca}^{2}+$ entry involves STIM1 and ORAI1 and it is essential to sustain the long-lasting $\mathrm{Ca}^{2+}$ oscillations during fertilization.

Interestingly, inhibiting store-operated $\mathrm{Ca}^{2+}$ entry in mouse eggs using known inhibitors or by the expression of protein fragments that interfere with STIM1-ORAI1 interaction did not prevent the sperm-induced $\mathrm{Ca}^{2+}$ oscillations raising the possibility that $\mathrm{Ca}^{2+}$ entry other than that regulated by the stores is responsible for sustaining the train of sperm-induced $\mathrm{Ca}^{2+}$ spikes (Miao et al. 2012, Takahashi et al. 2013). This may indicate species-specific differences and suggest that, at least in mouse eggs, ORAI1 proteins are not essential to provide $\mathrm{Ca}^{2+}$ influx in order to maintain the long-lasting $\mathrm{Ca}^{2+}$ signal. Potential candidates for this role may include trp channels that in several cell types mediate $\mathrm{Ca}^{2+}$ entry. Such channels are present in eggs (Petersen et al. 1995, Machaty et al. 2002) and certain types can be sensitized via phosphorylation by PKC (Hardie 2007), which would explain the above-mentioned stimulatory effect of PKC on the fertilization $\mathrm{Ca}^{2+}$ signal.

The potential mechanism that may operate during fertilization to sustain the repetitive $\mathrm{Ca}^{2+}$ signal is described in Fig. 1. The sperm delivers PLC $\zeta$ that hydrolyzes $\mathrm{PIP}_{2}$ into InsP $\mathrm{P}_{3}$ and DAG. InsP $\mathrm{P}_{3}$ binds to its receptor on the surface of the endoplasmic reticulum and triggers $\mathrm{Ca}^{2+}$ release from the intracellular store. $\mathrm{Ca}^{2+}$ is pumped out of the cell or bound to buffer proteins in the cytoplasm, thus replenishing of the store requires extracellular $\mathrm{Ca}^{2+}$. This may be mediated by STIM1: when it senses store depletion, STIM1 moves closer to the plasma membrane and opens storeoperated $\mathrm{Ca}^{2+}$ channels that let $\mathrm{Ca}^{2+}$ flow into the cell. SERCA pumps load $\mathrm{Ca}^{2+}$ back into the endoplasmic reticulum, so it will be available when another $\mathrm{Ca}^{2+}$ transient is generated. DAG produced by $\mathrm{PIP}_{2}$ hydrolysis may activate PKC that promotes $\mathrm{Ca}^{2+}$ influx through the entry channel and thereby facilitates store refilling. However, additional experiments are clearly needed to clarify the exact mechanism involved in the process.

The importance of transmembrane $\mathrm{Ca}^{2+}$ fluxes has been further highlighted by the results of a study mentioned earlier (Miao et al. 2012). In those experiments using mouse eggs, $\mathrm{Ca}^{2+}$ influx was found necessary not only to maintain the sperm-induced $\mathrm{Ca}^{2+}$ oscillations but also for the activation of critical signaling pathways. Following IVF or ICSI, blocking $\mathrm{Ca}^{2+}$ influx inhibited late activation events such as second polar body emission even in the presence of multiple $\mathrm{Ca}^{2+}$ transients. In addition, after a single sperm-induced $\mathrm{Ca}^{2+}$ spike, $\mathrm{Ca}^{2+}$ influx itself was sufficient to induce polar body extrusion and pronuclear formation. A similar phenomenon was observed before in somatic cells where only $\mathrm{Ca}^{2+}$ transients with accompanying $\mathrm{Ca}^{2+}$ influxes through store-operated $\mathrm{Ca}^{2+}$ channels were able to stimulate gene expression (Di Capite et al. 2009). These results are unexpected and seem to contradict earlier studies where the number of $\mathrm{Ca}^{2+}$ oscillations was the primary determinant of the temporal order of egg activation events (Ducibella et al. 2002, Tóth et al. 2006). They also mean, if confirmed, that subcellular localization of the $\mathrm{Ca}^{2+}$ elevation is important for successful initiation of embryo development and further strengthens the notion that $\mathrm{Ca}^{2+}$ influx is an integral part of the $\mathrm{Ca}^{2+}$ signaling mechanism in the egg.

\section{Concluding remarks}

It is generally accepted that transient elevations in the intracellular free $\mathrm{Ca}^{2+}$ concentration in the cytoplasm of the female gamete play important regulatory roles during development. The origin of $\mathrm{Ca}^{2+}$ is mostly intracellular, but influx across the plasma membrane is also important to shape the signal and determine its spatial and temporal dynamics. Efforts to characterize the $\mathrm{Ca}^{2+}$ influx pathway involved received impetus in recent years; however, a number of important questions remain to be clarified. PKC is known to regulate $\mathrm{Ca}^{2+}$ fluxes across the plasma membrane but the pathway through which it operates is not known. It is not clear whether it controls store-operated $\mathrm{Ca}^{2+}$ entry or alternatively its action is mediated by an entirely different mechanism. Transient receptor potential (trp) channels are also present in eggs; in somatic cell types, such channels are capable of mediating transmembrane $\mathrm{Ca}^{2+}$ fluxes and they might have a potential role in eggs as well. Additional experiments are needed to determine the contribution of store-operated $\mathrm{Ca}^{2+}$ entry to the fertilization $\mathrm{Ca}^{2+}$ signal in other species and to resolve the apparent discrepancies in recent published results. Finally, the exact function of the $\mathrm{Ca}^{2+}$ influx during fertilization also needs to be verified: whether it is needed simply for replenishing the stores or has other roles such as activating additional signaling cascades during egg activation. The information obtained through such studies will deepen our general understanding about $\mathrm{Ca}^{2+}$ signaling in the egg and may improve the efficiency of assisted reproductive technologies.

\section{Declaration of interest}

The authors declare that there is no conflict of interest that could be perceived as prejudicing the impartiality of this review. 


\section{Funding}

The experiments conducted to investigate store-operated $\mathrm{Ca}^{2+}$ entry in pig eggs were supported by Agriculture and Food Research Initiative Competitive Grant no. 2011-67015-30006 from the USDA National Institute of Food and Agriculture.

\section{Acknowledgements}

The authors wish to thank Dr Karl Swann for providing helpful feedback during the preparation of the manuscript.

\section{References}

Berridge MJ, Bootman MD \& Lipp P 1998 Calcium - a life and death signal. Nature 395 645-648. (doi:10.1038/27094)

Boni R, Cocchia N, Silvestre F, Tortora G, Lorizo R \& Tosti E 2005 Plasma membrane electrical properties and intracellular calcium stores in immature and in vitro matured adult and juvenile sheep oocytes. Reproduction, Fertility, and Development 17 279. (doi:10.1071/ RDv17n2Ab279)

Bootman MD, Collins TJ, Peppiatt CM, Prothero LS, MacKenzie L, De Smet P, Travers M, Tovey SC, Seo JT, Berridge MJ et al. 2001 Calcium signaling - an overview. Seminars in Cell \& Developmental Biology 12 3-10. (doi:10.1006/scdb.2000.0211)

Brandman O, Liou J, Park WS \& Meyer T 2007 STIM2 is a feedback regulator that stabilizes basal cytosolic and endoplasmic reticulum $\mathrm{Ca}^{2+}$ levels. Cell 131 1327-1339. (doi:10.1016/j.cell.2007.11.039)

Carroll J \& Swann K 1992 Spontaneous cytosolic calcium oscillations driven by inositol trisphosphate occur during in vitro maturation of mouse oocytes. Journal of Biological Chemistry 267 11196-11201.

Cheek TR, McGuinness OM, Vincent C, Moreton RB, Berridge MJ \& Johnson MH 1993 Fertilisation and thimerosal stimulate similar calcium spiking patterns in mouse oocytes but by separate mechanisms. Development 119 179-189.

Clapham DE 2007 Calcium signaling. Cell 131 1047-1058. (doi:10.1016/j. cell.2007.11.028)

Colonna R, Tatone C, Malgaroli A, Eusebi F \& Mangia F 1989 Effects of protein kinase $\mathrm{C}$ stimulation and free $\mathrm{Ca}^{2+}$ rise in mammalian egg activation. Gamete Research 24 171-183. (doi:10.1002/mrd.1120240205)

Cuthbertson KS \& Cobbold PH 1985 Phorbol ester and sperm activate mouse oocytes by inducing sustained oscillations in cell $\mathrm{Ca}^{2+}$. Nature 316 541-542. (doi:10.1038/316541a0)

Cuthbertson KS, Whittingham DG \& Cobbold PH 1981 Free $\mathrm{Ca}^{2+}$ increases in exponential phases during mouse oocyte activation. Nature 294 754-757. (doi:10.1038/294754a0)

Day M, Johnson MH \& Cook D 1995 Changes in inward peak Ca ${ }^{2+}$ current during progression of the cell cycle in early embryos. Proceedings of the Physiological Society 489 52P.

De Felici M \& Siracusa G 1982 Survival of isolated, fully grown mouse ovarian oocytes is strictly dependent on external $\mathrm{Ca}^{2+}$. Developmental Biology 92 539-543. (doi:10.1016/0012-1606(82)90198-1)

Dekel N \& Beers WH 1978 Rat oocyte maturation in vitro relief of cAMP inhibition by gonadotropins. PNAS 75 4369-4373. (doi:10.1073/pnas. 75.9.4369)

Di Capite J, Ng SW \& Parekh AB 2009 Decoding of cytoplasmic $\mathrm{Ca}^{2+}$ oscillations through the spatial signature drives gene expression. Current Biology 19 853-858. (doi:10.1016/j.cub.2009.03.063)

Downs SM 2010 Regulation of the G2/M transition in rodent oocytes. Molecular Reproduction and Development 77 566-585. (doi:10.1002/ $\operatorname{mrd} .21175)$

Ducibella T, Duffy P, Kurasawa S, Kopf GS \& Schultz RM 1991 The cortical reaction and modifications of the zona pellucida are stimulated by protein kinase $\mathrm{C}$ agonists in the mouse egg. Journal of Cell Biology 115 461a. (doi:10.1083/jcb.115.2.461)
Ducibella T, Huneau D, Angelichio E, Xu Z, Schultz RM, Kopf GS, Fissore R, Madoux S \& Ozil JP 2002 Egg-to-embryo transition is driven by differential responses to $\mathrm{Ca}^{2+}$ oscillation number. Developmental Biology 250 280-291. (doi:10.1006/dbio.2002.0788)

Edwards RG 1965 Maturation in vitro in mouse, sheep, cow, pig, rhesus monkey and human ovarian oocytes. Nature 208 349-351. (doi:10.1038/208349a0)

Endo Y, Kopf GS \& Schultz RM 1986 Stage-specific changes in protein phosphorylation accompanying meiotic maturation of mouse oocytes and fertilization of mouse eggs. Journal of Experimental Zoology 239 401-409. (doi:10.1002/jez.1402390311)

Eppig JJ \& Downs SM 1988 The role of purines in the maintenance of meiotic arrest in mammalian oocytes. Progress in Clinical Biological Research 267 103-113.

Fan HY, Liu Z, Shimada M, Sterneck E, Johnson PF, Hedrick SM \& Richards JS 2009 MAPK3/1(ERK1/2) in ovarian granulosa cells are essential for female fertility. Science 324 938-941. (doi:10.1126/science. 1171396)

Feske S, Gwack Y, Prakriya M, Srikanth S, Puppel SH, Tanasa B, Hogan PG, Lewis RS, Daly M \& Rao A 2006 A mutation in Orai1 causes immune deficiency by abrogating CRAC channel function. Nature 441 179-185. (doi:10.1038/nature04702)

Fujiwara T, Nakada K, Shirakawa H \& Miyazaki S 1993 Development of inositol trisphosphate-induced calcium release mechanism during maturation of hamster oocytes. Developmental Biology 156 69-79. (doi:10.1006/dbio.1993.1059)

Gilula NB, Epstein ML \& Beers WH 1978 Cell-to-cell communication and ovulation. A study of the cumulus-oocyte complex. Journal of Cell Biology 78 58-75. (doi:10.1083/jcb.78.1.58)

Gioia L, Barboni B, Turriani M, Capacchietti G, Ioannoni A, Lucidi P, Pistilli G \& Mattioli M 2005 P-type Ca channel activation by membrane depolarisation induces maturation in pig oocytes. Veterinary Research Communications 29 (Suppl 2) 195-198. (doi:10.1007/s11259-0050041-1)

Gómez-Fernández C, Pozo-Guisado E, Gañán-Parra M, Perianes MJ, Alvarez IS \& Martín-Romero FJ 2009 Relocalization of STIM1 in mouse oocytes at fertilization: early involvement of store-operated calcium entry. Reproduction 138 211-221. (doi:10.1530/REP-09-0126)

Gómez-Fernández C, López-Guerrero AM, Pozo-Guisado E, Álvarez IS \& Martín-Romero FJ 2012 Calcium signaling in mouse oocyte maturation: the roles of STIM1, ORAI1 and SOCE. Molecular Human Reproduction 18 194-203. (doi:10.1093/molehr/gar071)

Halet G, Tunwell R, Parkinson SJ \& Carroll J 2004 Conventional PKCs regulate the temporal pattern of $\mathrm{Ca}^{2+}$ oscillations at fertilization in mouse eggs. Journal of Cell Biology 164 1033-1044. (doi:10.1083/jcb. 200311023)

Hardie RC 2007 TRP channels and lipids: from Drosophila to mammalian physiology. Journal of Physiology 578 9-24. (doi:10.1113/jphysiol.2006. 118372)

Haverstick DM, Dicus M, Resnick MS, Sando JJ \& Gray LS 1997 A role for protein kinase $C \beta I$ in the regulation of $\mathrm{Ca}^{2+}$ entry in Jurkat $\mathrm{T}$ cells. Journal of Biological Chemistry 272 15426-15433. (doi:10.1074/jbc. 272.24.15426)

Homa ST 1991 Neomycin, an inhibitor of phosphoinositide hydrolysis, inhibits the resumption of bovine oocyte spontaneous meiotic maturation. Journal of Experimental Zoology 258 95-103. (doi:10.1002/jez. 1402580111)

Igusa Y \& Miyazaki S 1983 Effects of altered extracellular and intracellular calcium concentration on hyperpolarizing responses of the hamster egg. Journal of Physiology 340 611-632.

Igusa Y, Miyazaki S \& Yamashita N 1983 Periodic hyperpolarizing responses in hamster and mouse eggs fertilized with mouse sperm. Journal of Physiology 340 633-647.

Kaufman ML \& Homa ST 1993 Defining a role for calcium in the resumption and progression of meiosis in the pig oocyte. Journal of Experimental Zoology 265 69-76. (doi:10.1002/jez.1402650110)

Kawasaki T, Ueyama T, Lange I, Feske S \& Saito N 2010 Protein kinase C-induced phosphorylation of Orai1 regulates the intracellular $\mathrm{Ca}^{2+}$ level via the store-operated $\mathrm{Ca}^{2+}$ channel. Journal of Biological Chemistry 285 25720-25730. (doi:10.1074/jbc.M109. 022996) 
Kline D \& Kline JT 1992 Thapsigargin activates a calcium influx pathway in the unfertilized mouse egg and suppresses repetitive calcium transients in the fertilized egg. Journal of Biological Chemistry 267 17624-17630.

Koh S, Lee K, Wang C \& Machaty Z 2007 Characterization of STIM1 gene expression in porcine oocytes. Biology of Reproduction 77 (Suppl 1) 139.

Koh S, Lee K, Wang C, Cabot RA \& Machaty Z 2009 STIM1 regulates storeoperated $\mathrm{Ca}^{2+}$ entry in oocytes. Developmental Biology 330 368-376. (doi:10.1016/j.ydbio.2009.04.007)

Lee JH, Yoon SY \& Bae IH 2004 Studies on $\mathrm{Ca}^{2+}$-channel distribution in maturation arrested mouse oocyte. Molecular Reproduction and Development 69 174-185. (doi:10.1002/mrd.20162)

Lee K, Wang C \& Machaty Z 2012 STIM1 is required for $\mathrm{Ca}^{2+}$ signaling during mammalian fertilization. Developmental Biology 367 154-162. (doi:10.1016/j.ydbio.2012.04.028)

Lefevre B, Pesty A, Courtot AM, Martins CV, Broca O, Denys A, Arnault E, Poirot C \& Avazeri N 2007 The phosphoinositidephospholipase C (PI-PLC) pathway in the mouse oocyte. Critical Reviews in Eukaryotic Gene Expression 17 259-269. (doi:10.1615/CritRevEukarGeneExpr.v17.i4.10)

Liou J, Kim ML, Heo WD, Jones JT, Myers JW, Ferrell JE Jr \& Meyer T 2005 STIM is a $\mathrm{Ca}^{2+}$ sensor essential for $\mathrm{Ca}^{2+}$-store-depletion-triggered $\mathrm{Ca}^{2+}$ influx. Current Biology 15 1235-1241. (doi:10.1016/j.cub.2005.05.055)

Luciano AM, Franciosi F, Modina SC \& Lodde V 2011 Gap junctionmediated communications regulate chromatin remodeling during bovine oocyte growth and differentiation through cAMP-dependent mechanism(s). Biology of Reproduction 85 1252-1259. (doi:10.1095/ biolreprod.111.092858)

Machaty Z, Ramsoondar JJ, Bonk AJ, Bondioli KR \& Prather RS 2002 Capacitative calcium entry mechanism in porcine oocytes. Biology of Reproduction 66 667-674. (doi:10.1095/biolreprod66.3.667)

Madgwick S, Levasseur M \& Jones KT 2005 Calmodulin-dependent protein kinase II, and not protein kinase $\mathrm{C}$, is sufficient for triggering cell-cycle resumption in mammalian eggs. Journal of Cell Science 118 3849-3859. (doi:10.1242/jcs.02506)

Martín-Romero FJ, Ortíz-de-Galisteo JR, Lara-Laranjeira J, Domínguez-Arroyo JA, González-Carrera E \& Alvarez IS 2008 Store-operated calcium entry in human oocytes and sensitivity to oxidative stress. Biology of Reproduction 78 307-315. (doi:10.1095/ biolreprod.107.064527)

Mattioli M, Gioia L \& Barboni B 1998 Calcium elevation in sheep cumulusoocyte complexes after luteinizing hormone stimulation. Molecular Reproduction and Development 50 361-369. (doi:10.1002/(SICI)10982795(199807)50:3 < 361::AID-MRD13>3.0.CO;2-7)

McGuinness OM, Moreton RB, Johnson MH \& Berridge MJ 1996 A direct measurement of increased divalent cation influx in fertilised mouse oocytes. Development 122 2199-2206.

Mehlmann LM, Kalinowski RR, Ross LF, Parlow AF, Hewlett EL \& Jaffe LA 2006 Meiotic resumption in response to luteinizing hormone is independent of a Gi family $\mathrm{G}$ protein or calcium in the mouse oocyte. Developmental Biology 299 345-355. (doi:10.1016/j.ydbio.2006. 07.039)

Miao YL, Stein P, Jefferson WN, Padilla-Banks E \& Williams CJ 2012 Calcium influx-mediated signaling is required for complete mouse egg activation. PNAS 109 4169-4174.

Miyazaki S 1991 Repetitive calcium transients in hamster oocytes. Cell Calcium 12 205-216. (doi:10.1016/0143-4160(91)90021-6)

Miyazaki S \& Igusa Y 1981a Fertilization potential in golden hamster eggs consists of recurring hyperpolarizations. Nature 290 702-704. (doi:10.1038/290702a0)

Miyazaki S \& Igusa Y 1981 b Ca-dependent action potential and Ca-induced fertilization potential in golden hamster eggs. In The Mechanism of Gated Calcium Transport Across Biological Membranes, pp 305-311. Eds ST Ohnishi \& M Endo. New York: Academic Press.

Mohri T, Shirakawa H, Oda S, Sato MS, Mikoshiba K \& Miyazaki S 2001 Analysis of $\mathrm{Mn}^{2+} / \mathrm{Ca}^{2+}$ influx and release during $\mathrm{Ca}^{2+}$ oscillations in mouse eggs injected with sperm extract. Cell Calcium 29 311-325. (doi:10.1054/ceca.2000.0196)

Murnane JM \& De Felice LJ 1993 Electrical maturation of the murine oocyte: an increase in calcium current coincides with acquisition of meiotic competence. Zygote 1 49-60. (doi:10.1017/ S0967199400001295)
Norris RP, Ratzan WJ, Freudzon M, Mehlmann LM, Krall J, Movsesian MA, Wang H, Ke H, Nikolaev VO \& Jaffe LA 2009 Cyclic GMP from the surrounding somatic cells regulates cyclic AMP and meiosis in the mouse oocyte. Development 136 1869-1878. (doi:10.1242/dev.035238)

Paleos GA \& Powers RD 1981 The effect of calcium on the first meiotic division of the mammalian oocyte. Journal of Experimental Zoology $\mathbf{2 1 7}$ 409-416. (doi:10.1002/jez.1402170312)

Parekh AB \& Penner R 1995 Depletion-activated calcium current is inhibited by protein kinase in RBL-2H3 cells. PNAS 92 7907-7911. (doi:10.1073/pnas.92.17.7907)

Petersen CC \& Berridge MJ 1994 The regulation of capacitative calcium entry by calcium and protein kinase $C$ in Xenopus oocytes. Journal of Biological Chemistry $26932246-32253$.

Petersen CC, Berridge MJ, Borgese MF \& Bennett DL 1995 Putative capacitative calcium entry channels: expression of Drosophila trp and evidence for the existence of vertebrate homologues. Biochemical Journal 311 41-44.

Prakriya M 2009 The molecular physiology of CRAC channels. Immunological Reviews 231 88-98. (doi:10.1111/j.1600-065X.2009.00820.x)

Racowsky C 1986 The releasing action of calcium upon cyclic AMPdependent meiotic arrest in hamster oocytes. Journal of Experimental Zoology 239 263-275. (doi:10.1002/jez.1402390214)

Rink TJ \& Hallam TJ 1989 Calcium signalling in non-excitable cells: notes on oscillations and store refilling. Cell Calcium 10 385-395. (doi:10.1016/0143-4160(89)90064-X)

Roos J, DiGregorio PJ, Yeromin AV, Ohlsen K, Lioudyno $M$, Zhang S, Safrina O, Kozak JA, Wagner SL, Cahalan MD et al. 2005 STIM1, an essential and conserved component of store-operated $\mathrm{Ca}^{2+}$ channel function. Journal of Cell Biology 169 435-445. (doi:10.1083/jcb. 200502019)

Saunders CM, Larman MG, Parrington J, Cox LJ, Royse J, Blayney LM, Swann K \& Lai FA 2002 PLC $\zeta$ : a sperm-specific trigger of $\mathrm{Ca}^{2+}$ oscillations in eggs and embryo development. Development 129 3533-3544.

Shiina Y, Kaneda M, Matsuyama K, Tanaka K, Hiroi M \& Doi K 1993 Role of the extracellular $\mathrm{Ca}^{2+}$ on the intracellular $\mathrm{Ca}^{2+}$ changes in fertilized and activated mouse oocytes. Journal of Reproduction and Fertility 97 143-150. (doi:10.1530/jrf.0.0970143)

Silvestre F, Boni R, Fissore RA \& Tosti E $2011 \mathrm{Ca}^{2+}$ signaling during maturation of cumulus-oocyte complex in mammals. Molecular Reproduction and Development 78 744-756. (doi:10.1002/mrd.21332)

Streb H, Irvine RF, Berridge MJ \& Schulz I 1983 Release of $\mathrm{Ca}^{2+}$ from a nonmitochondrial intracellular store in pancreatic acinar cells by inositol-1,4,5-trisphosphate. Nature 306 67-69. (doi:10.1038/ 306067a0)

Stricker SA 1999 Comparative biology of calcium signaling during fertilization and egg activation in animals. Developmental Biology 211 157-176. (doi:10.1006/dbio.1999.9340)

Takahashi T, Kikuchi T, Kidokoro Y \& Shirakawa H $2013 \mathrm{Ca}^{2+}$ influxdependent refilling of intracellular $\mathrm{Ca}^{2+}$ stores determines the frequency of $\mathrm{Ca}^{2+}$ oscillations in fertilized mouse eggs. Biochemical and Biophysical Research Communications 430 60-65. (doi:10.1016/j. bbrc.2012.11.024)

Tombes RM, Simerly C, Borisy GG \& Schatten G 1992 Meiosis, egg activation, and nuclear envelope breakdown are differentially reliant on $\mathrm{Ca}^{2+}$, whereas germinal vesicle breakdown is $\mathrm{Ca}^{2+}$ independent in the mouse oocyte. Journal of Cell Biology 117 799-811. (doi:10.1083/jcb. 117.4.799)

Tosti E, Boni R \& Cuomo A $2000 \mathrm{Ca}^{2+}$ current activity decreases during meiotic progression in bovine oocytes. American Journal of Physiology. Cell Physiology 279 C1795-C1800.

Tóth S, Huneau D, Banrezes B \& Ozil JP 2006 Egg activation is the result of calcium signal summation in the mouse. Reproduction 131 27-34. (doi:10.1530/rep.1.00764)

Turner PR, Sheetz MP \& Jaffe LA 1984 Fertilization increases the polyphosphoinositide content of sea urchin eggs. Nature 310 414-415. (doi:10.1038/310414a0)

Vaccari S, Weeks JL II, Hsieh M, Menniti FS \& Conti M 2009 Cyclic GMP signaling is involved in the luteinizing hormone-dependent meiotic maturation of mouse oocytes. Biology of Reproduction 81 595-604. (doi:10.1095/biolreprod.109.077768) 
Van Den Brink GR, Bloemers SM, Van Den Blink B, Tertoolen LG Van Deventer SJ \& Peppelenbosch MP 1999 Study of calcium signaling in non-excitable cells. Microscopy Research and Technique 46 418-433. (doi:10.1002/(SICI)1097-0029(19990915)46:6<418::AIDJEMT9>3.0.CO;2-0)

Vig M, Peinelt C, Beck A, Koomoa DL, Rabah D, Koblan-Huberson $M$, Kraft S, Turner H, Fleig A, Penner R \& Kinet JP 2006 CRACM1 is a plasma membrane protein essential for store-operated $\mathrm{Ca}^{2+}$ entry. Science 312 1220-1223. (doi:10.1126/science.1127883)

Wang C, Lee K, Gajdócsi E, Bali Papp A \& Machaty Z 2012 Orai1 mediates store-operated $\mathrm{Ca}^{2+}$ entry during fertilization in mammalian oocytes. Developmental Biology 365 414-423. (doi:10.1016/j.ydbio.2012.03.007)

Webb RJ, Marshall F, Swann K \& Carroll J 2002 Follicle-stimulating hormone induces a gap junction-dependent dynamic change in [cAMP] and protein kinase A in mammalian oocytes. Developmental Biology 246 441-445. (doi:10.1006/dbio.2002.0630)

Whitaker M 2006 Calcium at fertilization and in early development. Physiological Reviews 86 25-88. (doi:10.1152/physrev.00023.2005)
Whitaker M \& Irvine RF 1984 Inositol 1,4,5-trisphosphate microinjection activates sea urchin eggs. Nature 312 636-639. (doi:10.1038/312636a0)

Yu Y, Halet G, Lai FA \& Swann K 2008 Regulation of diacylglycerol production and protein kinase $\mathrm{C}$ stimulation during sperm- and PLC $\zeta$ mediated mouse egg activation. Biology of the Cell 100 633-643. (doi:10.1042/BC20080033)

Zhang SL, Yeromin AV, Zhang XH, Yu Y, Safrina O, Penna A, Roos J, Stauderman KA \& Cahalan MD 2006 Genome-wide RNAi screen of $\mathrm{Ca}^{2+}$ influx identifies genes that regulate $\mathrm{Ca}^{2+}$ release-activated $\mathrm{Ca}^{2+}$ channel activity. PNAS 103 9357-9362. (doi:10.1073/pnas. 0603161103)

Received 7 December 2012

First decision 14 January 2013

Accepted 18 February 2013 